\title{
Vegetation and water quality responses to Holocene climate variability in Lake Purrumbete, western Victoria
}

\author{
John Tibby \\ Geography, Environment and Population, University of Adelaide, Adelaide, South Australia \\ john.tibby@adelaide.edu.au
}

\section{Dan Penny}

The University of Sydney, Sydney, NSW

\section{Paul Leahy}

Environment Protection Authority Victoria, Macleod, Victoria

\section{A. Peter Kershaw}

Monash University, Clayton, Victoria

\section{Introduction}

Palaeoenvironmental research can provide useful perspectives about the vulnerability and resilience of ecosystems to future climate change by documenting ecosystem response to past natural and human-induced environmental change (e.g. Dearing 2008, 2011). Such information is important since instrumental records for all but a few localities are non-existent, or are temporally short relative to ecological timescales (Smol 2008) and because ecosystem changes are, or will soon be, beyond the magnitude of anything witnessed in the historical period (Hansen 2005).

Between 1997 and 2010, lakes in western Victoria responded to prolonged hydrological deficit in a range of ways. Many dried out, while the vast majority underwent substantial changes in water quality and ecology (Leahy et al. 2010). Recent research has shown that a number of lakes once thought to be permanent landscape features are now subject to drying, while many 
other lakes are projected to be seasonally dry by the end of the $21^{\text {st }}$ century (Leahy et al.2010). The present water quality and ecology of Western District Ramsar-listed lakes (lakes Beeac, Bookar, Colongulac, Corangamite, Cundare, Gnarput, Milangil, Murdeduke and Terangpom) bears little resemblance to their conditions when listed under the Ramsar agreement in 1982, and most have been at least seasonally dry over the past decade. Given that there has been a very substantial reduction in the number of western Victorian lakes, including those recognised as nationally and internationally significant, ecosystem preservation in the remaining lakes is paramount. Of the numerous lakes in western Victoria, a small number of deeper sites $(>5 \mathrm{~m}$ deep) will persist throughout the 21 st century, even with marked hydrological deficit (Kirono et al. 2009). Given that deep lakes will be important landscape refugia over this century, prudent management is important. Although the limnology of western Victorian lakes is relatively well studied (e.g. Timms 1976; De Deckker 1983; De Deckker and Williams 1988; Tibby and Tiller 2007), there is still considerable uncertainty about their likely future behaviour. With the aim of enhancing understanding of its possible future behaviour, this study focuses on the environmental history of one such lake: Lake Purrumbete, the deepest natural freshwater lake in Victoria.

Previous palaeoenvironmental studies at Lake Purrumbete have been undertaken by De Deckker (1982) and Yezdani (1970). However, these studies were based on records that were undated and also, in the case of Yezdani (1970), short. Yezdani (1970) briefly described the pollen and algae (including diatoms) at a coarse resolution from a core collected near the edge of the lake. All the samples were post-European, as indicated by the presence of Pinus pollen throughout the record. De Deckker's (1982) macrofossil record for Purrumbete was not radiocarbon dated, however the $580 \mathrm{~cm}$ record was suggested to cover about 6000-7000 years, an inference largely consistent with the results herein. De Deckker (1982) inferred a constantly fresh lake with water depth $>35 \mathrm{~m}$ throughout the record. However, the proxies used by De Deckker did not allow fine-scale estimation of palaeoclimatic changes.

Lake Purrumbete has one of the longest records of continuous water-quality monitoring in Victoria (Mitchell and Collins 1987; Tibby and Tiller 2007). These data are important to the management of this and other lake systems. In particular, such data can be used to predict future responses to climate change through coupling with dynamic climate modelling such as the Kirono et al.'s (In press) modelling of salinity response to predicted climate in the western Victorian lakes Bullenmerri, Gnotuk and Keilambete. Although valuable, such exercises are limited because modelling of climate-driven biological responses is considerably more difficult than predicting physical responses (such as changes in lake depth, salinity or stratification). Climate projections for southwestern Victoria consistently predict increased temperature, while rainfall estimates are somewhat more variable (i.e. while most model predictions infer future declines in rainfall, some suggest there may be rainfall increases, CSIRO and BOM 2007). However, the combined effect of temperature increases and changes in rainfall is likely to result in reductions in effective precipitation (Kirono et al. In press). Combining future climate scenarios with the observed behaviour of lakes makes it possible to hypothesise about the response of lakes to future warming, although it is axiomatic that such models are calibrated over short time periods relative to often lengthy ecosystem responses to climate change.

Building on the earlier research of Mitchell and Collins (1987), Tibby and Tiller (2007) analysed the relationship between Lake Purrumbete water quality and climate for the period 1984-2000. In line with expectations, they demonstrated that lake salinity (measured as electrical conductivity) increased in response to reduced effective moisture and that water temperature was strongly correlated with air temperature. In addition, they also showed that there was a strong negative relationship between air temperature and nutrient concentrations (specifically total phosphorus) in the water column $\left(r^{2}=0.61, p<0.005, n=165\right)$. Tibby and Tiller (2007) 
suggest that periods of increased temperature lead to lengthened periods of water column stratification. This, in turn, results in nutrients being depleted from the epiliminion through the uptake of phosphorus by algae, which eventually sink, sequestering nutrients to the sediments.

Based on a combination of these observations about future warming and Lake Purrumbete's relationship to measured climate, it appears that future change may be expected to increase water temperature and salinity, while decreasing average water-column nutrient concentrations. In order to assess this scenario, therefore, we utilised a long-term record of environmental change preserved in Lake Purrumbete sediments to examine the nature of the Lake's response to (past) climate change, with a view to more fully understanding the possible nature of future change. This approach arose from observations that the diatom records from this and other western Victorian lakes including Lake Surprise (Tibby et al. 2006) and Tower Hill Lake (D'Costa et al. 1989) exhibit very marked shifts during the Holocene, suggesting lacustrine conditions that are very different to those recorded in even relatively long monitoring time series.

Our analysis focuses predominantly on the pollen and diatom record derived from a $6 \mathrm{~m}$ Mackereth core extracted from Lake Purrumbete in the late 1990s. In addition, pollen data are derived from an associated frozen spade core, representing an undisturbed record of the most recently deposited sediments. We utilise the record of precipitation-evaporation ratio (P:E) derived from nearby Lakes Keilambete, Gnotuk and Bullenmerri (Jones et al. 1998, see Figure 1 for site locations) as a means of interpreting the response of the aquatic and terrestrial ecosystems in Lake Purrumbete and its surrounds to climate variability. Although there are differing interpretations of the precise timing of changes in these records (particularly from the most intensively studied Lake Keilambete), there is a coherent record of effective precipitation inferred by a number of authors using a variety of proxies including sediment grain size and composition, ostracod composition and shell chemistry, and pollen (Dodson 1974; Bowler 1981; De Deckker 1982; Chivas et al. 1985; Jones et al. 1998), which, importantly, have been observed in other lakes in the region (Gell 1998; Tibby et al. 2006). While it is not possible to de-couple the separate effects of precipitation and evaporation in Jones et al.'s (1998) record, it nevertheless provides a quantitative estimate of effective moisture through the Holocene. Hence, we use the P:E record as a reference point to examine how water quality and vegetation in and around Lake Purrumbete responded to arid and humid phases during the Holocene. Importantly, the inferred effective moisture history from western Victoria can be compared with the inferred effective moisture history predicted for the region (Kirono et al. 2009), allowing future likely changes to be placed in context.

\section{Study site}

Lake Purrumbete is a large, fresh, clear-water, alkaline, eutrophic maar crater (see Table 1 for summary water-quality information). It has a maximum breadth of more than $2.8 \mathrm{~km}$, a maximum depth of $45 \mathrm{~m}$, a surface area of more than $5.5 \mathrm{~km}^{2}$ and a volume of $157 \mathrm{x} 106$ $\mathrm{m}^{3}$ (Timms 1976). Vegetation surrounding the lake, as for the region in general, is heavily modified by recent land use. Remnant native vegetation can be broadly classified as grasslands or open grassy woodlands (Kershaw et al. 2004), with strong edaphic controls on vegetation apparent, particularly with respect to the distribution of soils weathered from basalt (D'Costa et al. 1989).

Ecological studies of Lake Purrumbete began in the late 1960s (Hussainy 1969; Yezdani 1970; Timms 1976). Both Hussainy (1969) and Yezdani (1970) noted the presence of spring blooms of Melosira granulata (=Aulacoseira granulata) over a period of three years. Gasse et al. (1997) showed that the dominant planktonic diatoms in the centre of Lake Purrumbete sampled in sediment traps, and to a lesser extent phytoplankton sweeps, were Cyclotella meneghiniana 


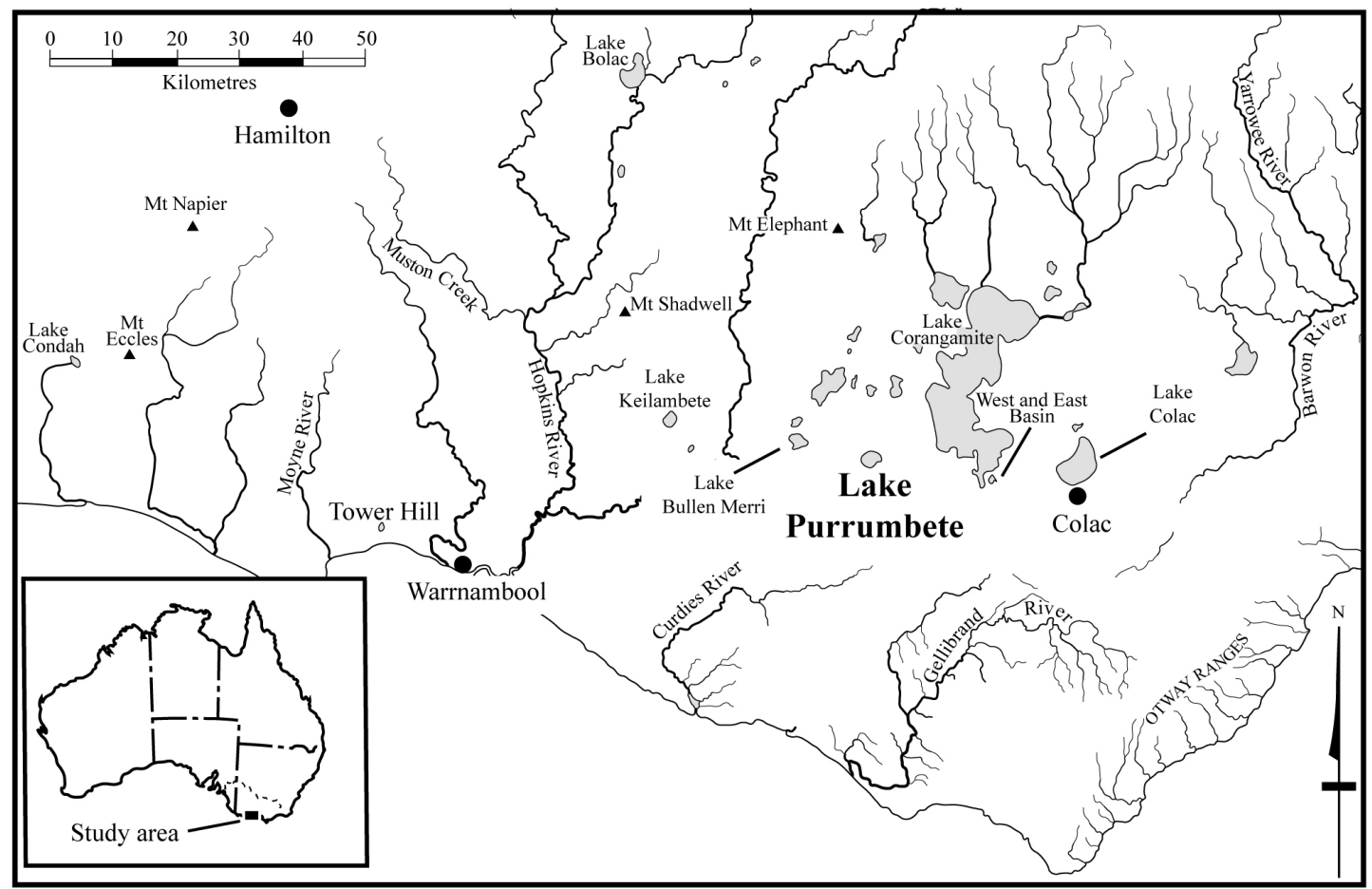

Figure 1. Location of Lake Purrumbete and other sites referred to in the text.

Table 1. Summary of water quality data from Lake Purrumbete 1984-2000. See Tibby and Tiller (2007) for details of methods.

\begin{tabular}{|l|l|l|l|}
\hline Variable & Unit & Average & n determinations \\
\hline Water temperature & ${ }^{\circ} \mathrm{C}$ & 15.2 & 179 \\
\hline Electrical conductivity & $\mathrm{HS} \mathrm{^{-1 }}$ & 739 & 180 \\
\hline $\mathrm{pH}$ & $\mathrm{pH} \mathrm{Units}$ & 8.6 & 175 \\
\hline Total nitrogen & $\mathrm{mg} \mathrm{l}^{-1}$ & 0.792 & 178 \\
\hline Total phosphorus & $\mathrm{mg} \mathrm{l}^{-1}$ & 0.102 & 178 \\
\hline Orthophosphate $\left(\mathrm{PO}_{4}\right)$ & $\mathrm{mg} \mathrm{l}^{-1}$ & 0.083 & 176 \\
\hline Dissolved oxygen & $\mathrm{mg} \mathrm{l}^{-1}$ & 9.749 & 180 \\
\hline Turbidity & $\mathrm{NTU}$ & 1.155 & 148 \\
\hline Secchi depth & metres & 4.6 & 81 \\
\hline
\end{tabular}

and Aulacoseira granulata. Interestingly, they also noted that, in summer phytoplankton sweeps, the epiphytic diatom Cocconeis placentula is the most abundant diatom, despite the substantial distance of their study site from the shoreline.

Despite the relative longevity of ecological study at Lake Purrumbete, palaeoecology can provide additional information to facilitate better lake management. For example, aquatic macrophyte surveys in the late 1960s (Yezdani 1970) did not detect the current dominant macrophyte in the lake Vallisneria americana var. americana (EPA Victoria, unpub. data). In the late 1960s, Myriophyllum spp. were dominant (Yezdani 1970). Mitchell and Collins (1987) detected Vallisneria gigantea (= Vallisneria americana var. americana) in Lake Purrumbete by 1984. From the perspective of lake managers, it is not clear whether the current dominance by Vallisneria is related to recent shifts in climate, the lake nutrient status, or part of natural variability.

\section{Methods}

Sediment coring was undertaken from an anchored floating platform close the centre of the lake. A near $6 \mathrm{~m}$ long core, $5 \mathrm{~cm}$ in diameter, was collected with a Mackereth sampler 
(Mackereth 1958). As the corer tends to disturb or fail to collect very unconsolidated surface sediments, material from the topmost $1 \mathrm{~m}$ was retrieved intact on a frozen spade (Neale and Walker 1996).

Samples of $1 \mathrm{~cm}^{3}$ were taken at $10 \mathrm{~cm}$ intervals $(n=59)$ from the Mackereth core and prepared for diatom analysis using a modification of Battarbee (1986), where three-hour treatments in $10 \% \mathrm{HCl}$ and $10 \% \mathrm{H}_{2} \mathrm{O}_{2}$ were used to remove carbonate and organic matter, respectively. Following these treatments, samples were rinsed repeatedly in distilled water, and they were then mounted using Naphrax mounting medium. Diatoms were identified using 1000x magnification with a Zeiss Axioskop fitted with differential interference contrast, with Krammer and Lange-Bertalot $(1986,1988,1991 \mathrm{a}, \mathrm{b})$ the main source of taxonomic information. A minimum of 300 valves were counted per sample, with diatom abundances calculated using the microspheres method described in Battarbee (1986).

Separation cells of Aulacoseira granulata were identified, as Gomez et al. (1995) have shown that $A$. granulata forms a larger number of separation cells during periods of stratification, so that its filament (or "chain") is shorter, rendering it easier for such chains to remain suspended in poorly mixed water columns.

Samples of $2 \mathrm{~cm}^{3}$ of wet sediment were extracted from the core and the frozen spade for pollen analysis, with sampling resolution increasing from a maximum of $0.4 \mathrm{~m}$ below $3.0 \mathrm{~m}$ depth to a minimum of $0.04 \mathrm{~m}$ in the frozen-spade sample, which represents the upper $0.6 \mathrm{~m}$ of the pollen record $(n=37)$. The Mackereth core and the frozen-spade sample were correlated using the first appearance of introduced Pinus pollen in both records as a biostratigraphic marker. The samples were prepared following the method of van der Kaars et al. (2000) and pollen grains counted at 400x magnification with an Olympus $\mathrm{CH}-2$ microscope. Pollen counts ranged between 133 and 406, with an average of 259 palynomorphs per sample. Taxonomy was based primarily on an extensive modern reference set in the School of Geography and Environmental Science, Monash University. Pollen and spore counts are expressed as abundance relative to a standardised dryland pollen sum for southeastern Australia (D'Costa and Kershaw 1997). Banksia was excluded from the standard pollen sum in order to avoid distortion in the data set due to extreme over-representation of this taxon at $0.4 \mathrm{~m}$ depth in the core. Pollen and diatom relative abundance data (excluding Banksia and taxa $<1 \%$ respectively) were classified into zones using a stratigraphically constrained cluster analysis with Euclidean distance as the similarity metric (Grimm 1987). Pollen and diatom zone boundaries were established at arbitrary thresholds of 0.6 and 3.0 respectively.

Four pollen concentrates (prepared following Regnell 1992) were submitted for accelerator mass spectrometry radiocarbon dating (Fink et al.2004). Radiocarbon ages (BP) were calibrated (cal BP) using the INTCAL09 dataset (Reimer et al. 2009) in the programme CALIB 6.0 (Stuiver and Reimer 1986). The resulting calibrated ages (Table 2) have a near-linear relationship with depth $\left(r^{2}=0.992\right)$, and a simple linear regression was used as a basis for the chronological model used in Figures 2 and 3.

\section{Results}

Diatom and pollen results are presented in Figures 2 and 3, respectively. Diatom zone 4 is characterised by the highest relative abundances of non-planktonic taxa in the record, although the planktonic Aulacoseira granulata is the species with the highest individual relative abundance. Of the non-planktonic diatoms, the major taxa are Fragilaria aff. zeilleri, Pseudostaurosira brevistriata, Staurosirella pinnata and Staurosira elliptica. The relative abundance of nonplanktonic diatoms, both in total and individually, is lower in Zone 3. Zone 2 is dominated by Aulacoseira granulata and the concentration of diatoms is lowest in this zone. In Zone 1, 
Table 2. Results of AMS radiocarbon analysis on pollen concentrates. ${ }^{14} \mathrm{C}$ ages are calibrated using the program CALIB 6.0 (Stuiver and Reimer 1986) with the INTCAL 09 dataset (Reimer et al. 2009). Ages are reported at $1 \sigma(68.3 \%)$ and $2 \sigma(95.4 \%)$ confidence, and the relative area of the probability distribution for each intercept of the calibration curve is given in square brackets.

\begin{tabular}{|c|c|c|c|c|c|}
\hline Depth $(\mathrm{cm})$ & Lab code & ${ }^{14} \mathrm{C}$ age BP & \% modern C & Cal BP $(1 \sigma)$ & Cal BP $(2 \sigma)$ \\
\hline $64-65$ & OZG077 & $450 \pm 35$ & $94.55 \pm 0.37$ & $494-526[1]$ & $\begin{array}{l}340-347[0.013] \\
459-540[0.987]\end{array}$ \\
\hline $275-278$ & OZG076 & $3660 \pm 40$ & $63.38 \pm 0.31$ & $\begin{array}{l}3903-3991[0.771] \\
4041-4072[0.229]\end{array}$ & $3865-4088$ [1] \\
\hline $405-408$ & $0 Z G 075$ & $4970 \pm 40$ & $53.84 \pm 0.26$ & $5652-5746[1]$ & $\begin{array}{l}5606-5758[0.849] \\
5822-5885[0.151]\end{array}$ \\
\hline $575-577$ & $0 Z G 074$ & $7160 \pm 50$ & $41.03 \pm 0.24$ & $\begin{array}{l}7880-7887[0.061] \\
7932-8003[0.939]\end{array}$ & $7848-8026$ [1] \\
\hline
\end{tabular}

Discostella stelligera is the dominant diatom in every sample, although its abundance is lower in the upper four samples. The concentration of diatoms is highest in Zone 1.

The pollen record has been divided into three zones based on stratigraphically constrained cluster analysis. Zone 3 (580-170 cm depth; ca. 7600-1700 cal BP) is consistently dominated by Poaceae pollen, averaging $40 \%$ of the pollen sum. Common sclerophyll woodland taxa (Eucalyptus, Casuarinaceae) are strongly represented with some variability but no clear trend. Cyperaceae and Myriophyllum are the most commonly recorded aquatic pollen types in this zone, but their abundance is low and highly variable. The common dryland pollen types are stable throughout Zone 2 (160-36 cm; ca. 1500-150 cal BP), with a slight decline in the relative abundance of Causarinaceae pollen as depth decreases. The very high values for Banskia recorded at $40 \mathrm{~cm}$ depth are likely a result of over-representation, perhaps due to the interment of flower parts in the sediment, and are not taken as indicative of a change in catchment vegetation. Cyperaceae pollen becomes more abundant, with some variability, through Zone 2 , reaching a maximum at $44 \mathrm{~cm}$ depth $(190 \mathrm{cal} \mathrm{BP})$. Zone 1 of the pollen record $(32-0 \mathrm{~cm}$ depth; 130 cal BP-present) is characterised by a dramatic increase in the relative abundance of Poaceae pollen (to an average of $83 \%$ of the pollen sum), and concomitant decreases in all other dryland pollen taxa in the sum. Pollen from exotic plants (Pinus, Plantago lanceolata, Cupressaceae) appears for the first time in the record at $40 \mathrm{~cm}$ depth (ca. $170 \mathrm{cal} \mathrm{BP}$ ) and increases dramatically to a maximum relative abundance at $16 \mathrm{~cm}$ depth (ca. $50 \mathrm{cal} \mathrm{BP}$ ). Myriophyllum pollen increases at the Zone 2/Zone 1 boundary, to reach a maximum value in Zone 1 at $16 \mathrm{~cm}$ depth (ca. $50 \mathrm{cal} \mathrm{BP}$ ), the strongest representation of that taxon for the entire record. This pattern is not apparent in any of the other aquatic plants in the record (Triglochin, Ruppia, Potamogeton). Cyperaceae, most probably occupying a narrow littoral margin of the steep-sided crater, is poorly and irregularly represented in Zone 1.

\section{Discussion}

\section{Diatom and inferred water-quality response to Holocene climate variability}

There have been substantial and dramatic changes to the Lake Purrumbete diatom community since $8000 \mathrm{cal} \mathrm{BP}$, with some species completely absent from the early or late part of the record and rapid shifts in the abundance of the dominant and sub-dominant taxa. In Zone 4, from approximately 8000 to $5500 \mathrm{cal} \mathrm{BP}$, non-planktonic diatoms, particularly taxa in the Fragiliariaceae, are more numerous in total than planktonic species, although the planktonic diatom Aulacoseira granulata is the single most abundant species. Aulacoseira granulata, although variable, declines through this period. Of the non-planktonic species, Fragilaria aff. zeilleri is the most abundant. However, the taxonomic and therefore the ecological affinity of this taxon is uncertain, apart from the likelihood that, similar to other chain-forming Fragiliariaceae 
(Bennion et al. 2001; Sayer 2001), it is not planktonic. The second most abundant nonplanktonic diatom is Pseudostaurosira brevistriata, which peaks in the middle part of this zone. Pseudostaurosira brevistriata, Staurosirella pinnata and Staurosira elliptica are abundant in shallow lakes ( $<5 \mathrm{~m}$ deep) in Australia (e.g. Gell et al. 2002; Tibby et al. 2007) and elsewhere (Bennion et al. 2001; Sayer 2001).

Given that Lake Purrumbete is currently $>40 \mathrm{~m}$ deep and that De Deckker (1982) suggests that there is little evidence for marked lake level changes in the lake, the high relative abundance of non-planktonic diatoms $8000-5500 \mathrm{cal} \mathrm{BP}$ is intriguing, since it would tend to indicate, $a$ priori, a lake depth considerably shallower than $40 \mathrm{~m}$. This is particularly the case since other palaeoenvironmental records from the region (e.g. Bowler 1981; D'Costa et al. 1989) and Jones et al.'s (1998) P:E record indicate that this period was one of maximum water availability (with $\mathrm{P}: \mathrm{E}$ up to 1.1 during this period). The abundance of Aulacoseira granulata in combination with the Fragiliariaceae provides a possible insight into this conundrum since Aulacoseira granulata is a diatom that requires turbulent mixing to remain suspended in the water column (Bormans and Webster 1999). Hence, it is likely that the high relative abundance of this colonial taxon, as opposed to solitary planktonic species such as Discostella stelligera and Cyclostephanos dubius, represents times when wind-generated mixing is elevated (see Wang et al. 2008). Thus, it is possible that the relatively high representation of the Fragiliariaceae may result from these taxa being transported to the central lake environment by the same mixing that advantaged $A$. granulata. Notably, Gasse et al. (1997) report that a large proportion of diatoms they inferred to be derived from the littoral zone were found in centre-lake sediment traps from Lake Purrumbete.

From approximately $5500 \mathrm{cal} \mathrm{BP}$ to $4000 \mathrm{cal} \mathrm{BP}$ (Zone 3), the dominant diatom is the planktonic species Cyclostephanos dubius, which generally increases in relative abundance through this zone (Figure 2). This taxon is abundant during a period of decreased effective moisture where the precipitation:evaporation ratio was between 0.89 and 0.94 (Jones et al. 1998) (see Figure 2). Indeed, the dominance of Cyclostephanos dubius commences concurrently with an inferred step change in regional moisture at $5500 \mathrm{cal} \mathrm{BP}$ (Jones et al. 1998). Cyclostephanos dubius is commonly found in lakes with elevated nutrient concentrations (Bradshaw and Anderson 2003). In northwest European lakes, it has a total phosphorus optimum of $176 \mu \mathrm{g} \mathrm{l}^{-1}$ (Bradshaw and Anderson 2003), while Tibby (2004) derived an optimum of $76 \mu \mathrm{g} \mathrm{TP} \mathrm{l}^{-1}$ for Cyclostephanos aff. dubius (maximum relative abundance $<9 \%$ ), which may be closely related to C. dubius, in southeast Australian water storages. C. dubius has not been recorded in modern Australian lake sediments at abundances as great as in the Lake Purrumbete record, including in western-Victorian diatom calibration data sets (Gell 1997; Barr 2010).

Given Tibby and Tiller's (2007) observation that water-column nutrient concentrations decrease in Lake Purrumbete as a result of persistent stratification during extended warming, it might be expected that the decreased effective moisture experienced from $5500 \mathrm{cal} \mathrm{BP}$ to $3500 \mathrm{cal} \mathrm{BP}$ would be associated with decreased, rather than increased, nutrient concentrations. Despite this, the increasing abundance of $C$. dubius in the mid Holocene mirrors the decreased moisture witnessed in Lakes Keilambete, Bullenmerri and Gnotuk. As a result, while it could be expected that nutrients would be removed from the water column as a result of longer periods of stratification associated with higher temperatures, and/or less nutrients being delivered to the lake via rainfall, epilimentic nutrient concentrations in Lake Purrumbete remained high through this period.

There was a relatively rapid turnover of species between $4000 \mathrm{cal} \mathrm{BP}$ and $3500 \mathrm{cal} \mathrm{BP}$, with Cyclostephanos dubius giving way to Discostella stelligera after a short (approximately 500-year) phase of Aulacoseira granulata dominance. The sustained abundance of Aulacoseira granulata, with its requirement for water column turbulence, likely indicates a period of greater wind 


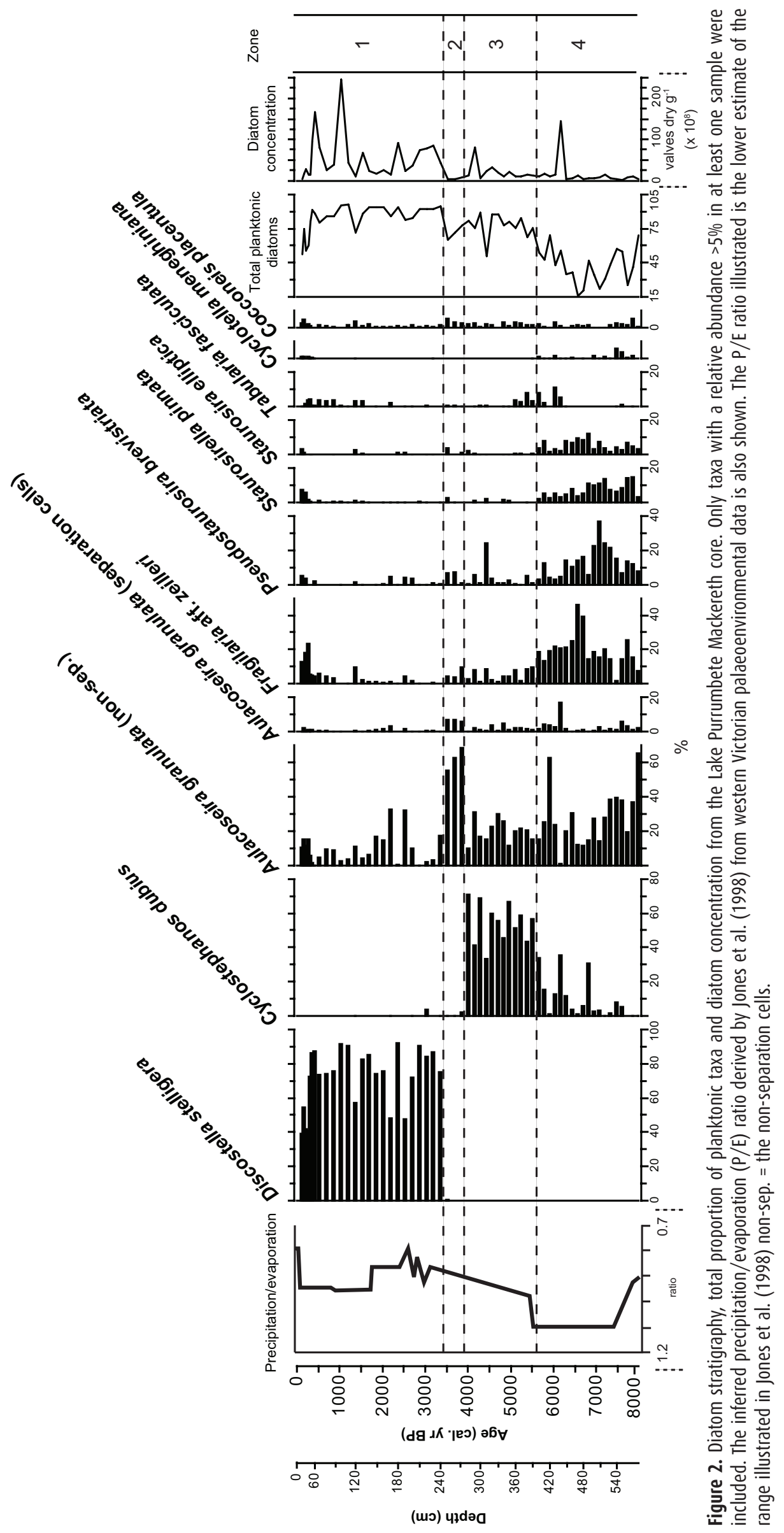


generated mixing during this time.

For approximately the past 3500 years, the diatom community in Lake Purrumbete has been dominated by Discostella stelligera, a freshwater planktonic species that, in high relative abundances such as observed in the Lake Purrumbete record, is indicative of oligotrophic waters (see Tibby 2004 and references therein). Discostella stelligera, which has a total phosphorus optimum of $16 \mu \mathrm{g} \mathrm{l}^{-1}$, dominates the record at a time of substantial climatic variability and persists through relatively arid and relatively wet phases during which, for example, trees grew at the edges of lakes Keilambete and Bullenmerri and were subsequently drowned approximately 2000 years ago (Bowler 1981). Indeed, the period from $3100 \mathrm{cal} \mathrm{BP}$ to $2000 \mathrm{cal} \mathrm{BP}$ is one of substantial climate variability in western Victoria, with two $>5 \mathrm{~m}$ oscillations in the level of Lake Keilambete recorded during this time and with the inferred P/E of 0.78 at $2500 \mathrm{cal}$ BP the lowest recorded since the early Holocene (Jones et al. 1998). However, apart from this period being largely coincidental with the onset of the Discostella stelligera dominance in the Lake Purrumbete record, there is little to differentiate it from the period of sustained higher moisture availability between $2000 \mathrm{cal} \mathrm{BP}$ and $110 \mathrm{cal} \mathrm{BP}$ where P/E reached 0.95 (see Figure 2). Arguably, Cyclotella stelligera may have been advantaged relative to Cyclostephanos dubius from $3100 \mathrm{cal} \mathrm{BP}$ to $2000 \mathrm{cal} \mathrm{BP}$ because the conditions which resulted in increased aridity (e.g. a reduction in winter storm tracks delivering moisture to the region) advantaged this smaller, less silicified taxon in a more stratified lake environment. The persistence of this taxon following this period (i.e. post $2000 \mathrm{cal} \mathrm{BP}$ ), however, is less explicable, but it appears to highlight a degree of resistance to substantial climate variability.

\section{Vegetation response to Holocene climate variability and European impact}

In contrast to the dramatic changes apparent in the diatom record, the overriding characteristic of the Lake Purrumbete pollen record is one of stability though the greater part of the Holocene. All of the common dryland pollen types maintain, with some variability, their values over time. The Casuarinaceae are perhaps the only exception, with a decrease in relative abundance from around $4000 \mathrm{cal} \mathrm{BP}$. The apparent stability of Eucalyptus and Chenopodiaceae pollen throughout this period does not appear to support soil salinisation as a likely cause of the decline in Casuarinaceae in our record (sensu Crowley 1994) and it is not clear whether the data presented here are in fact part of the broader decline in Casuarinaceae observed at a number of sites in the western Victorian Basaltic Province (see Kershaw et al. 2004). The muted vegetation response to the climatic changes known to have occurred in the area, and particularly to the relatively arid and variable climatic conditions centred around 3000-4000 BP (Bowler and Hamada, 1971; Bowler 1981; Chivas et al. 1985, 1986; Figure 3) which are shown here to have had dramatic implications for the freshwater ecology of Lake Purrumbete, is remarkable, and has been noted elsewhere (Dodson 1974, p. 716-717, 2001, Dodson et al. 2004). We conclude that the amplitude and/or duration of climatic variability during the Holocene did not exceed the resilience (sensu Holling 1973) of the sclerophyll woodland flora.

As with other vegetation records from western Victoria, the impact of non-indigenous land-use practices since the early part of the 19th century (from $32 \mathrm{~cm}$ depth in our record) is dramatic, reflecting the expansion of grasslands at the expense of woodland and forest, and the introduction of exotic plants. It is unclear what processes are driving the increase in Myriophyllum pollen during this period of European settlement. Gell et al. (1993), citing Orchard's (1985) seminal work on the genus, interpreted similar recent increases in Myriophyllum pollen as evidence of mass-flowering following stranding of Myriophyllum beds. Arguably, similar patterns at other lakes from the region (Tower Hill, main lake, zone ML1; D'Costa et al. 1989; Cobrico Crater, central core; Dodson et al.2004) imply that recent changes in the aquatic flora are perhaps indicative of some regional phenomenon, rather than site-specific variability in 


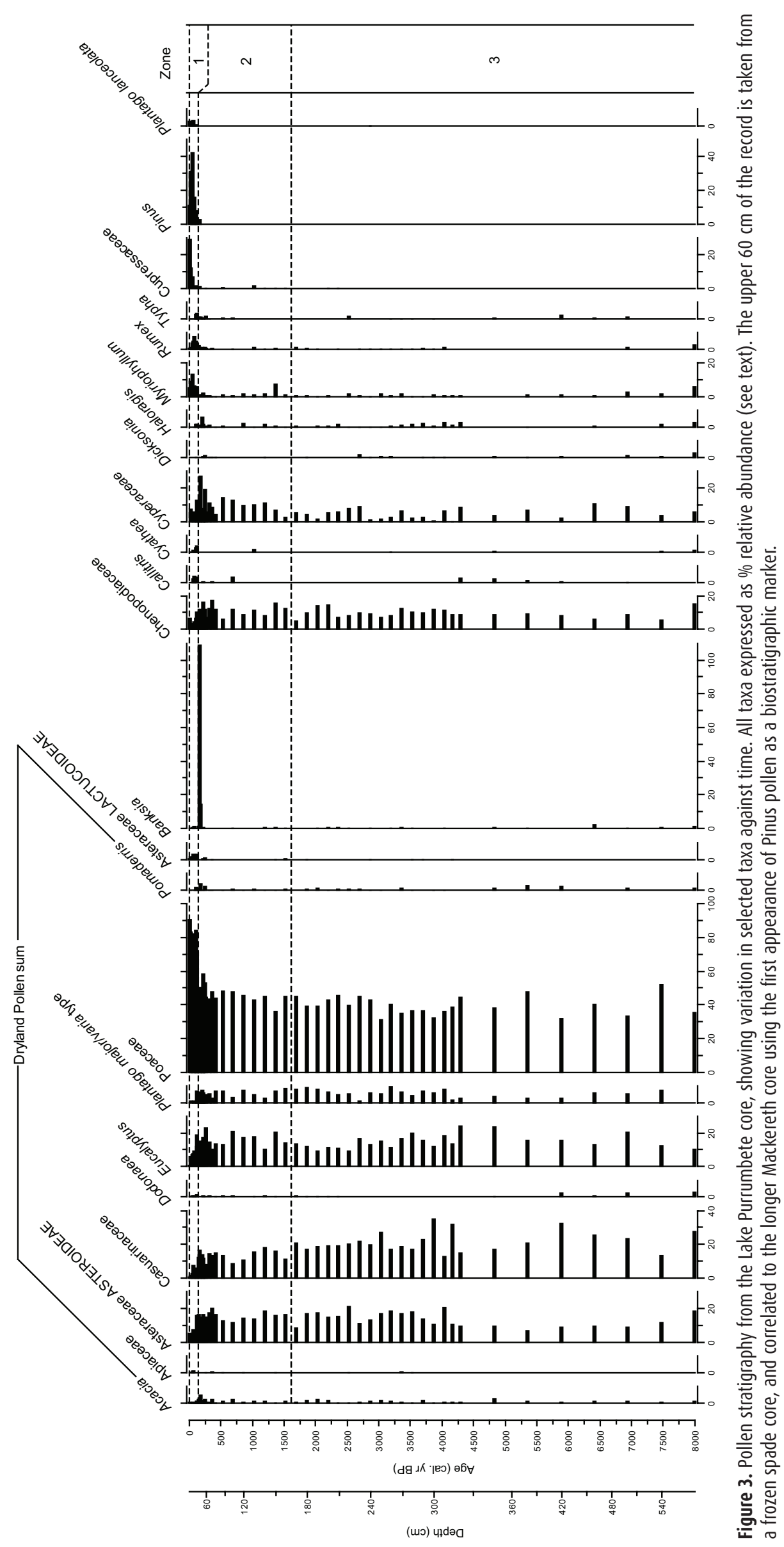


water levels.

\section{Implications for understanding lake response to future climate change}

In many Western District lakes, salinity concentrations are highly sensitive to climate (Kirono et al. 2009; Leahy et al. 2010) and recent climate-driven salinity increases have led to losses in biodiversity (Leahy et al. 2010). Future climate changes will further increase the loss of diversity in many western district Lakes. Although salinity in Lake Purrumbete is related to climate (Tibby and Tiller 2007, Yihdego 2010), modelled salinity increases over the coming decades are predicted to be moderate (Yihdego 2010) and not likely to result in large losses of diversity. Given the relative resilience of Lake Purrumbete to future climate driven salinity increases, factors such as macrophyte abundance and algal dynamics, which themselves are mediated by nutrient concentrations, are much more likely to be future drivers of diversity in Lake Purrumbete.

The Lake Purrumbete diatom record indicates that water quality, in particular nutrient status, can exhibit both marked sensitivity and apparent resilience to climate variation. The former is most amply demonstrated by the transition from dominance of a species associated with high nutrient concentrations, Cyclostephanos dubius, to Discostella stelligera, a taxon with markedly lower nutrient status. By contrast, resistance to environmental change is seen by the continued dominance of Discostella stelligera through lengthy periods of contrasting lateHolocene climate. Similarly, the palaeoenvironmental record shows that macrophytes like Myriophyllum have exhibited resilience over thousands of years, and then a late-Holocene rapid rise in abundance. This then provides lake managers with evidence that the rapid changes in Myriophyllum observed in the historical period have not occurred previously in the Holocene. In combination, these data suggest that while lakes such as Lake Purrumbete may 'resist' a degree of climate variability, when shifts do occur they are likely to be more abrupt, sustained and severe than can be predicted from even lengthy monitoring. From a lake-management perspective, climate-driven changes in mixing regime and nutrient cycling may propagate large and sudden changes in lake ecology. Hence, lake managers should give priority to reducing diffuse sources of nutrients to the lake to minimise the risks associated with changes in nutrient status.

\section{Conclusion}

The diatom record from Lake Purrumbete indicates that large lake systems can undergo rapid and sustained shifts in their water quality and ecology in response to climate change, even when lake levels show only minor alterations to climate perturbation (De Deckker 1982). Moreover, the limnological sensitivity of Lake Purrumbete to climatic variability is shown to be much greater than the catchment vegetation. It is clear that the limnology of Lake Purrumbete during the early to mid-Holocene was notably different to that of the late Holocene. Indeed, as with other lakes in the region, it appears that water-column nutrient concentrations in this lake were elevated, relative to the time of settlement, from 8000 to approximately 3500 years ago. As a result, the record of past environmental change in lakes such as this can provide an otherwise unobtainable insight into the behaviour of these systems.

\section{Acknowledgements}

JT, DP and PL thank Peter Kershaw for guidance and inspiration over many years. We thank Patrick De Deckker and Cameron Barr for informative discussions. The comments of two reviewers are also appreciated. This research was supported by AINSE grant 02/098P. The late Gary Swinton drew Figure 1. 


\section{References}

Barr, C. 2010. Droughts and flooding rains: a fine-resolution reconstruction of climatic variability in western Victoria, Australia, over the last 1500 years. Unpublished $\mathrm{PhD}$ thesis, University of Adelaide.

Battarbee, R.W. 1986. Diatom Analysis. In: Berglund, B.E. (ed), Handbook of Holocene palaeoecology and palaeohydrology, pp. 527-570. John Wiley and Sons, Chicester.

Bennion, H., Appleby, P.G. and Phillips, G.L. 2001. Reconstructing nutrient histories in the Norfolk Broads, UK: implications for the role of diatom-total phosphorus transfer functions in shallow lake management. Journal of Paleolimnology 26:181-204.

Bormans, M. and Webster, I.T. 1999. Modelling the spatial and temporal variability of diatoms in the River Murray. Journal of Plankton Research 21:581-598.

Bowler,J.M. 1981. Australian salt lakes. A palaeohydrological approach. Hydrobiologia 82:431-444.

Bowler, J.M. and Hamada, T. 1971. Late Quaternary stratigraphy and radiocarbon chronology of water level fluctuations in Lake Keilambete, Victoria. Nature 232:330-332.

Bradshaw, E.G. and Anderson N.J. 2003. Environmental factors that control the abundance of Cyclostephanos dubius (Bacillariophyceae) in Danish lakes, from seasonal to century scale. European Journal of Phycology 38:265-276.

Chivas, A.R., De Deckker, P. and Shelley,J.M.G. 1985. Strontium content of ostracods indicate lacustrine palaeosalinity. Nature 316:251-253.

Chivas A.R., De Deckker, P., Shelley, J.M.G. 1986. Magnesium and strontium in non-marine ostracod shells as indicators of palaeosalinity and temperature. Hydrobiologia 143:135-142.

Commonwealth Scientific and Industrial Research Organisation (CSIRO) and Bureau of Meteorology (BOM) 2007. Climate change in Australia. Commonwealth Scientific and Industrial Research Organisation.

Crowley, G.M. 1994. Quaternary soil salinity events and Australian vegetation history. Quaternary Science Reviews 13:15-22.

D'Costa, D., Edney, P., Kershaw, A.P. and De Deckker,P.1989. Late Quaternary palaeoecology of Tower Hill, Victoria, Australia. Journal of Biogeography 16:461-482.

D'Costa, D. and Kershaw, A.P. 1997. An expanded recent pollen database from south-eastern Australia and its potential for refinement of palaeoclimatic estimates. Australian Journal of Botany 45:583-605.

De Deckker, P. 1982. Holocene ostracods, other invertebrates and fish remains from cores of four maar lakes in southeastern Australia. Proceedings of the Royal Society of Victoria 94:183-219.

De Deckker, P. 1983. Australian salt lakes: their history, chemistry, and biota - a review, Hydrobiologia 105:231-244.

De Deckker, P. and Williams, W.D. 1988. Physico-chemical limnology of eleven, mostly saline permanent lakes in western Victoria. Hydrobiologia 162:275-286.

Dearing,J.A. 2008. Landscape change and resilience theory: a palaeoenvironmental assessment from Yunnan, SW China. The Holocene 1:117-127.

Dearing, J.A. 2011. Learning from the Past. Global Change 77:16-19.

Dodson, J.R. 1974. Vegetation and climatic history near Lake Keilambete, western Victoria. Australian Journal of Botany 22:709-717.

Dodson, J.R. 2001. Holocene vegetation change in the mediterranean-type climate regions of Australia. The Holocene 11: 673-680.

Dodson, J.R., Frank, K., Fromme, M., Hickson, D., McRae, V., Mooney, S. and Smith, J.D. 2004. Environmental systems and human impact at Cobrico Crater, south-western Victoria. Australian Geographical Studies 32:27-40. 
Fink, D., Hotchkis, M., Hua, Q. Jacobsen, G., Smith, A.M., Zoppi, U., Child, D., Mifsud, C., van der Gaast, H., Williams, A. and Williams, M. 2004. The ANTARES AMS facility at ANSTO. Nuclear Instruments and Methods in Physics Research Section B: Beam Interactions with Materials and Atoms. 223-224:109-115.

Gasse, F., Barker, P.A., Gell, P.A., Fritz, S.C. and Chalie F. 1997. Diatom-inferred salinity of palaeolakes, an indirect tracer of climate change. Quaternary Science Reviews 16:547-563.

Gell P.A. 1997. The development of diatom database for inferring lake salinity, western Victoria, Australia: Towards a quantitative approach for reconstructing past climates. Australian Journal of Botany 45:389-423.

Gell, P.A. 1998. Quantitative reconstructions of the Holocene palaeosalinity of paired crater lakes based on a diatom transfer function. Palaeoclimates 3(1-3):83-96.

Gell, P.A., Sluiter, I.R. and Fluin, J. 2002. Seasonal and inter-annual variations in diatom assemblages in Murray River-connected wetlands in northwest Victoria, Australia. Marine and Freshwater Research 53:981-992.

Gell, P.A., Stuart, I.-M. and Smith, J.D. 1993. The response of vegetation to changing fire regimes and human activity in East Gippsland, Victoria, Australia. The Holocene 3:150-160.

Gomez, N., Riera,J.L. and Sabater, S. 1995. Ecology and morphological variability of Aulacoseira granulata (Bacillariophyceae) in Spanish reservoirs. Journal of Plankton Research 17(1):1-16.

Grimm, E.C. 1987. CONISS: a FORTRAN 77 program for stratigraphically constrained cluster analysis by the method of incremental sum of squares. Computers and Geosciences 13(1):13-35.

Hansen, J.E. 2005. A slippery slope: How much global warming constitutes "dangerous anthropogenic interference"? Climatic Change 68:269-279.

Holling, C.S. 1973. Resilience and the Stability of Ecological Systems. Annual Review of Ecology and Systematics 4:1-23.

Hussainy, S.U.1969. Ecological studies on some microbiota of lakes in western Victoria. Unpublished $\mathrm{PhD}$ thesis. Monash University. 254 pp.

Jones, R.N., McMahon, T.A. and Bowler,J.M.1998. A high resolution Holocene record of P/E ratio from closed lakes, western Victoria. Palaeoclimates 3(1-3):51-82.

Kershaw, A.P., Tibby, J. Penny, D., Yesdani, H., Walkley, R., Cook, E. and Johnston, R. 2004. Latest Pleistocene and Holocene vegetation and environmental history of the western plains of Victoria. Proceedings, Royal Society of Victoria 116:141-163.

Kirono, D.G.C., Kent, D.M, Jones, R.N. and Leahy, P.J. 2009. Modelling lake levels under climate change conditions: three closed lakes in Western Victoria. In: Anderssen, R.S., Braddock R.D. and Newham L.T.H. (eds), 18th World IMACS Congress and MODSIMO9 International Congress on Modelling and Simulation. Modelling and Simulation Society of Australia and New Zealand and International Association for Mathematics and Computers in Simulation. pp. 4312-4318.

Kirono, D.G.C., Kent, D.M., Jones, R.N. and Leahy, P.J. In press. Assessing climate change impacts and risks on three salt lakes in Western Victoria, Australia. Human and Ecological Risk Assessment.

Krammer, K. and Lange-Bertalot, H. 1986. Bacillariophyceae. 1: Teil: Naviculaceae. Gustav Fischer Verlag, Jena.

Krammer, K. and Lange-Bertalot, H. 1988. Bacillariophyceae. 2: Teil: Bacillariaceae, Epthimiaceae, Surirellaceae. Gustav Fischer Verlag, Jena.

Krammer, K. and Lange-Bertalot, H. 1991a. Bacillariophyceae. 3: Centrales, Fragilariaceae, Eunotiaceae. Gustav Fischer Verlag, Stuttgart.

Krammer, K. and Lange-Bertalot, H. 1991b. Bacillariophyceae. 4: Achnanthes, Kritische Ergänzunhen zu Navicula (Lineolatae) und Gomphonema Gesamtliteraturverzeichnis Teil 1-4. Gustav Fischer Verlag, Stuttgart. 
Leahy, P.J., Robinson, D., Patten, R. and Kramer,A. 2010 Lakes in the Western District of Victoria and Climate Change. EPA Science Report. http://www.epa.vic.gov/publications/

Mitchell, B.D. and Collins, R. 1987. A limnological study of Lake Purrumbete. Part A. Introduction, methods and physico-chemical parameters. Report 87-3A. Centre for Aquatic Sciences, Warrnambool Institute of Advanced Education.

Mackereth, F.J.H. 1958. A portable core sampler for lake deposits. Limnology and Oceanography 3:181-191.

Orchard, A.E. 1985. Myriophyllum (Haloragaceae) in Australasia. II. The Australian Species. Brunonia 8:173-291.

Neale,J.L. and Walker, D. 1996. Sampling sediment under warm deep water. Quaternary Science Revierws 15:581-590.

Regnell, J. 1992. Preparing pollen concentrates for AMS dating - a methodological study from a hard-water lake in southern Sweden. Boreas 21:373-377.

Reimer, P.J., Baillie, M.G.L., Bard, E., Bayliss, A., Beck, J.W., Blackwell, P.G., Ramsey, C.B., Buck, C.E., Burr, G.S., Edwards, R.L., Friedrich, M., Grootes, P.M., Guilderson, T.P., Hajdas, I., Heaton, T.J., Hogg, A.G., Hughen, K.A., Kaiser, K.F., Kromer, B., McCormac, F.G., Manning, S.W., Reimer, R.W., Richards, D.A., Southon, J.R., Talamo, S., Turney, C.S.M., van der Plicht, J. and Weyhenmeyer, C.E. 2009. IntCal09 and Marine09 radiocarbon age calibration curves, 0-50,000 years CAL BP. Radiocarbon 51:1111-1150.

Sayer, C.D. 2001. Problems with the application of diatom-total phosphorus transfer functions: examples from a shallow English lake. Freshwater Biology 46:743-757.

Smol, J.P. 2008. Pollution of Lakes and Rivers: A Paleoenvironmental Perspective. Malden, MA, Blackwell.

Stuiver, M. and Reimer, P.J. 1986. A computer program for radiocarbon age calibration. Radiocarbon 28:1022-1030.

Tibby, J. 2004. Development of a diatom-based model for inferring total phosphorus in southeastern Australian water storages. Journal of Paleolimnology 31:23-36.

Tibby, J. and Tiller, D. 2007. Climate-water quality relationships in three Western Victorian (Australia) lakes 1984-2000. Hydrobiologia 591:219-234.

Tibby, J., Kershaw, A.P., Builth, H., Philibert, A. and White, C. 2006. Environmental change and variability in south-western Victoria: changing constraints and opportunities for occupation and land use. In: David, B., Barker, B. and McNiven, I.J. eds), The Social Archaeology of Australian Indigenous Societies, pp. 254-269. Canberra, Aboriginal Studies Press.

Tibby, J., Gell, P.A., Fluin, J. and Sluiter, I. 2007. Diatom-salinity relationships in wetlands: assessing the influence of salinity variability on the development of inference models. Hydrobiologia 591:207-218.

Timms, B. 1976. A comparative study of the limnology of three maar lakes in western Victoria. I. Physiography and physicochemical features. Marine and Freshwater Research 27:35-60.

van der Kaars, S., Wang, X., Kershaw, P., Guichard, F. and Setiabudi, D.A. 2000. A late Quaternary palaeoecological record from the Banda Sea, Indonesia: patterns of vegetation, climate and biomass burning in Indonesia and northern Australia. Palaeogeography, Palaeoclimatology, Palaeoecology 155:135-153.

Wang, L., Lu, H., Liu, J., Gu, Z., Mingram, J., Chu, G., Li, J., Rioual, P., Negendank, J.F.W., Han, J. and Liu, T. 2008. Diatom-based inference of variations in the strength of Asian winter monsoon winds between 17,500 and 6000 calendar years B.P. Journal Geophysical Research 113(D21):D21101.

Yezdani, G.H. 1970. A study of the Quaternary vegetation history in the volcanic lakes region of western Victoria. Unpublished $\mathrm{PhD}$ thesis. Monash University. $570 \mathrm{pp}$. 
Yihdego, Y. 2010. Modelling of lake level and salinity for Lake Purrumbete in western Victoria. Latrobe University unpublished report. 